\title{
An integrative review of literature: virtual exchange models, learning outcomes, and programmatic insights
}

\author{
Anna Zak ${ }^{1}$
}

Abstract

his integrative review explores English language publications to determine trends present in Virtual Exchange (VE) research over a span of ten years. The L review presents a brief introduction to VE, highlights key scholars in the field, and describes various VE models. In addition, learning outcomes and programmatic insights present in current scholarship are categorized and examined. This review can serve as a helpful tool for practitioners new to VE, as well as for scholars interested in expanding the VE research field.

Keywords: virtual exchange; integrative literature review; collaborative online international learning (COIL); learning outcomes.

\section{Introduction}

Research indicates that study abroad programs provide a gateway for students to expand their world view and become more open minded and accepting of others (Byker \& Putman, 2019; Cushner, 2007; Salisbury, An, \& Pascarella, 2013; Slotkin, Durie, \& Eisenberg, 2012; Varela, 2017; Walters, Garii, \& Walters, 2009). In fact, the impactful and pivotal learning that takes place in study abroad programs is still limited to only $10 \%$ of U.S. college students (Rubin, 2016a). In addition, over 50\% of study abroad programs take place in Europe (NAFSA, 2018). In an effort to create more access to global

1. St. John's University, United States; zaka@stjohns.edu; https://orcid.org/0000-0001-8889-9548

How to cite this article: Zak, A.. (2021). An integrative review of literature: virtual exchange models, learning outcomes, and programmatic insights. Journal of Virtual Exchange, 4, 62-79. https://doi.org/10.21827/jve.4.37582 
learning opportunities and to diversify the geographic reach of such interactions for those students who cannot study or travel abroad due to financial, physical, or other limitations, some higher education institutions have introduced VE programs. VE programs offer an online global experience facilitated through the Internet as a cost effective and safer alternative to study abroad (O'Dowd, 2018; Ruiz-Corbella, 2014; Rubin, 2016a, 2017). This technology-enabled learning serves as a virtual study abroad that is embedded within a university course. VE is facilitated through continuous communication and interaction between two or more geographically separated faculty (Akbaba \& Başkan, 2017; Custer \& Tuominen, 2016; Li, 2012; Rubin, 2016a, 2017). VE courses allow students to engage in academic discussions, collaborative projects, and joint lectures coordinated by the local faculty and their international counterparts without leaving their national borders (Barbier \& Benjamin, 2019; Guadamillas Gómez, 2017; O’Dowd, 2018, 2019; Rubin, 2016a, 2017).

According to the American Association of Colleges and Universities, Global/Diversity Learning is one of 11 high impact educational practices found to increase student engagement and retention (Kuh, O’Donnell, \& Reed, 2013). Thus, universities and colleges offer and promote study abroad opportunities to students in an attempt to engage and to retain them, as well as to prepare them for employment in the competitive global market. In fact, the National Association of Colleges and Employers (NACE) indicates that multicultural fluency is one of the top eight competencies that employers are currently seeking (NACE, 2019). In 2018, CultureWizard conducted a survey of whitecollar employees from 90 countries and found that $89 \%$ of them complete at least some of their work in Global Virtual Teams (GVTs), where team members are culturally diverse and geographically separate relying only on online tools for communication (CultureWizard, 2018). Taras and colleagues (2021) conducted a study of employees working in GVTs and found that the benefits and challenges of working on these teams are centered around how teams manage personal and contextual diversity. They recommend cross-cultural communication and diversity awareness training as well as training on online communication and collaboration tools as a way to prepare employees to work on GVTs (Taras et al., 2021). Thus, benefits of global learning afforded by such experiences as study abroad have clear positive implications on retention, engagement, and employability of college students. Yet, higher education institutions struggle to ensure that all students have the opportunity to gain global and multicultural competencies during their time in college (Abrahamse et al., 2014; Reysen \& Katzarska-Miller, 2013; Reysen, Larey, \& Katzarska-Miller, 2012; Rubin, 2017). Rubin (2017) states that less than $10 \%$ of university students in the United States and Western Europe are able to partake in experiences abroad (including short-term programs and travel). These numbers are significantly lower when looking at students at U.S. based community colleges where only less than $0.1 \%$ have access to such experiences. The rest of the world has similarly low numbers of student participation estimated at less than 1\% of all university students (Rubin, 2017). Because the ability to study and travel abroad is often only afforded to those students with financial means and the 
physical ability and freedom to travel abroad for extended periods of time, a large portion of the college population is denied access to these experiences (Lörz, Netz, \& Quast, 2016). This furthers the marginalization of students from lower socioeconomic backgrounds, students with different abilities, students with dependents, undocumented students, and students who must maintain employment in order to support themselves or their dependents. These students continue to lack access to global experiences, which would allow them to gain the global/multicultural fluency that employers seek in today's competing job market. Considering these limitations coupled with the increase in unrest, natural disasters, and the most recent worldwide pandemic, coupled with the prevalence of employees working on GVTs (Taras et al., 2021), VE has the potential for exponential growth as educational systems throughout the world are looking for a safe, less expensive, and more inclusive way to provide global experiences to their students. Thus, an integrative literature review - one which pulls together the existing scholarship on the topic of VE and works to define and understand concepts and trends in the body of research (Onwuegbuzie \& Frels, 2016) present in English language publications, can be helpful in shaping the future trajectory of VE research in the U.S. In addition, such a review has the potential to help future practitioners design their VE programs by building on current VE trends and work to overcome the existing challenges and limitations.

\section{Foundational text and key scholars}

A notable amount of material on the topic of VE has been produced by four scholars whose names are worth highlighting. O'Dowd is the leader in the field having authored and co-authored a larger majority of articles on VE and telecollaboration (a model of VE). Consequently, O'Dowd's work is widely cited in the scholarship on VE. His most recent work presents an argument that VE programing needs to move away from reflective state to a more action-oriented state, challenging that students should take interculturally informed action to address global issues rather than simply discuss and reflect on them (O’Dowd, 2019). He even proposes a model of VE that would serve to facilitate such action-based learning and thus aid with global citizenship development.

Other contributors to both scholarly and practitioner resources worth noting include Rubin, who has written extensively on VE, and in particular on the Collaborative Online International Learning (COIL) - a VE model originated from the State University of New York (SUNY) where Rubin served as the director of the COIL center for many years. Rubin advocates for VE programs on the basis that they provide inclusion for students who might not have the means or ability to study abroad. He provides implementation and program design guidance for those interested in teaching a COIL course (Guth \& Rubin, 2015; Rubin, 2016a, 2017). Another important scholar in the field is Helm, whose research focuses on language learning in the VE context and touches on program design. Helm's most recent 
work offers an important critique as she debunks four commonly held assumptions about language learning in the VE context (Helm, 2017). Finally, Guth's (2019) scholarship, which encompasses language learning, teacher training, and practitioner advice in relation to $\mathrm{VE}$ is of great importance. In addition, Guth recently begun exploring global citizenship development in the context of VE. The work of these four scholars is fundamental to gaining a deeper understanding of the field of VE.

\section{Methodology}

An integrative review is categorized as both a narrative and a systematic review. It combines the review of empirical and theoretical scholarship to help obtain a holistic understanding of a particular topic, and thus represents the broadest type of literature review (Onwuegbuzie \& Frels, 2016). The methodology used for this integrative literature review is outlined by explaining the search strategies, databases, key words, and phrases utilized during the discovery process. Further, an outline of the selection and exclusion criteria is provided, followed by a discussion of the process used to determine which articles to include as well as an explanation of the justification for setting these criteria.

\subsection{Search strategies}

The literature for this review was generated through a comprehensive search of U.S. based databases such as: Education Resources Information Center (ERIC), ProQuest, Google Scholar, and the library at a U.S. Higher Education Institution. In addition, I set up an automated search in Mendeley using the key words and phrases outlined in the inclusion criteria section. Mendeley periodically generates emails containing the titles of the most recent articles published on the topic.

The initial search was conducted using the following key words and phrases: VE + Learning Outcomes and VE + Models within the title or abstract of the article. The search was then expanded to include the following key words and phrases: (1) International VE + Learning Outcomes and (2) COIL + Learning Outcomes. Later, as I read through the articles generated by these search phrases, an additional VE model caught my attention and the phrase (3) Telecollaboration + Learning Outcomes was added to further expand the search. Based on these search criteria a total of 181 sources were found (see Table 1 for more details), many of the sources were not related to VE and were in fact about virtual reality, technology, or telecommunication and were thus eliminated. After reviewing the titles and abstracts, 65 sources were selected to be read in full. Using the inclusion and exclusion criteria described below, 27 sources (eight scholarly articles, eight reports, ten book chapters, and one handbook) were selected to be included in this integrative literature review as they covered 
information related to VE models, learning outcomes, and programmatic insights - information helpful to a researcher or practitioner beginning to learn about the VE field.

\subsection{Inclusion criteria}

Since VE is a fairly new topic of scholarship, the inclusion and exclusion criteria were refined a few times throughout the search process. The inclusion criteria set at the beginning was to include only English language articles published in U.S. peer-reviewed journals, yet since the scholarship on this topic is still emerging, this parameter was expanded to include practitioner-based resources, book chapters, and books. All sources were available in English, and the search was limited to U.S. scholarly databases. Although inclusion of articles from outside of the U.S. was not the focus of this review, a few of the articles included in this review are authored by international scholars. In the future, it would be important to expand the search to international databases and to include articles written in languages other than English to provide a more balanced view of the VE landscape, inclusive of the perspectives of the international partners and educational institutions beyond the U.S. context.

Initially, there weren't any parameters set in reference to the date of publication because the goal was to become familiar with the available scholarship on the topic in a broader sense in order to discover trends present in current literature and formulate research question(s) for further research of the VE field. Later on, the parameters to search for articles published between 2009 and 2019 (the last ten years) were put in place to ensure that the literature was recent and that the findings were robust and well rounded. These parameters also ensured that the research would be conducted on VE programs which would have utilized similar technology, as by 2009 the iPhone and Skype, which allowed for easy access to videoconferencing, were widely used by the public (Chen, 2017; Wearden, 2011).

Once I found studies using these key words and phrases, I read the article's title and the abstract and assessed them to determine whether the study concerned one or more of the three key search areas: VE Learning Outcomes; VE models (which included all of the following: Global Learning Experience, COIL, Xculture, Virtual Teams, E-tandem, telecollaboration, Online Intercultural Exchange, Soliya, International Educational Exchange); and VE programmatic insights. Studies were excluded if they did not focus on higher education to stay consistent with the parameters of the study. Articles pertaining to both undergraduate and graduate students' experience were included. Additionally, articles about practitioner experience, program design/models, and curriculum of the VE program were included to provide a holistic understanding of VE in higher education settings. The 27 sources selected for a full read were then coded according to the main themes discussed in each text, then 
the themes were grouped into categories of VE models, Learning Outcomes, and programmatic insights. Table 1 below details the search outcomes per database.

\section{Table 1. Search outcomes per database}

\begin{tabular}{|l|l|l|l|l|l|l|l|}
\hline Database & Total & $\begin{array}{l}\text { Scholarly } \\
\text { Journals }\end{array}$ & Magazines & Books & Reports & $\begin{array}{l}\text { ERIC } \\
\text { Documents }\end{array}$ & $\begin{array}{l}\text { Number } \\
\text { Selected }\end{array}$ \\
\hline ProQuest & 32 & 32 & 0 & 0 & 0 & - & 9 \\
\hline ERIC & $\mathbf{6 1}$ & $\mathbf{1 0}$ & $\mathbf{0}$ & $\mathbf{3}$ & $\mathbf{2 6}$ & $\mathbf{2 2}$ & $\mathbf{5}$ \\
\hline Google Scholar & 81 & 33 & 20 & 7 & 21 & - & 10 \\
\hline Mendeley & $\mathbf{7}$ & 0 & 0 & 0 & 0 & - & 3 \\
\hline Total & $\mathbf{1 8 1}$ & $\mathbf{7 5}$ & $\mathbf{2 0}$ & $\mathbf{1 0}$ & $\mathbf{4 7}$ & $\mathbf{2 2}$ & $\mathbf{2 7}$ \\
\hline
\end{tabular}

\section{Findings}

This section provides an integrative review of the literature on VE found in English language publications available with U.S. scholarly databases over the span of ten years. In an attempt to provide a holistic understanding of the trends in the body of scholarship on the topic of VE to date, this review answers the following guiding questions: (1) What are some of the VE models discussed in literature? (2) What are the major learning outcomes of VE? and (3) What are the programmatic insights (trends, challenges, limitations) addressed in literature?

\subsection{VE present scholarship landscape}

As an emerging field of study, VE is viewed by scholars as an innovative and novel pedagogical technique being applied in a variety of academic fields of study (O’Dowd \& Lewis, 2016; Rubin, 2016a; Thorne, 2016). Much of the existing scholarship on the topic addresses VE somewhat generally, providing programmatic overviews and outlining challenges and benefits (Abrahamse et al., 2014; Akbaba \& Başkan, 2017; Caluianu, 2019; Guth \& Rubin, 2015; Helm, 2018; Rubin, 2016a). The research is mostly qualitative and consists of case studies, which offer detailed accounts of specific VE programs and are not meant to be generalized. Some of the commonalities that emerged are that VE has been most often used with the intention of language learning (e.g. Barbier \& Benjamin, 2019; Guadamillas Gómez, 2017; Hagley, 2016; Helm, 2017; Helm \& Guth, 2012), peacebuilding (e.g. ElliottGower \& Hill, 2015) and developing international cultural competencies (e.g. Abrahamse et al., 2014; Akbaba \& Başkan, 2017). Further, many of the VEs have taken place between the U.S. and European partners, although there is an indication that a growing number of geographic regions engaging in this practice is beginning to surface (e.g. Abrahamse et al., 2014; Elliott-Gower \& Hill, 2015; Hagley, 
2016; Li, 2012). It is evident that English tends to be the main language used in facilitating VEs when language learning is not the goal of the program; in some cases this poses challenges and sparks criticism. Several of the scholars in the field focus on studying VE as a new pedagogical technique (e.g. Guth \& Rubin, 2015; Rubin, 2016b, 2017; Ruiz-Corbella, 2014; O’Dowd, 2018). Thus, little attention has been given to the practical components of designing and implementing VE programs. Insight of that sort is present in the practitioner-based resources, which share timelines, technological testing tips, and design models, but do not provide empirical evidence to support these planning and programmatic decisions (Custer \& Tuominen, 2016; De Wit, 2016; Elliott-Gower \& Hill, 2015; Guth \& Rubin, 2015). Furthermore, very few studies discuss practitioner attitudes and perceptions (Bassani \& Buchem, 2019; Helm \& Guth, 2012).

\subsection{Overview of virtual exchange}

In an attempt to provide global opportunities to students who are unable to travel abroad, many universities are attempting to utilize technology to afford students virtual global experiences and peer-to-peer interactions. Rubin (2017) argues that in response to this lack of access, "COIL was coined in 2006 and more recently "virtual exchange”' (p. 29). Although such international collaborations did take place prior to COIL, they were often conducted by individual faculty without institutional support. The current VE landscape features numerous VE models situated both in higher education institutions and international organizations/institutions dedicated to facilitating them (Rubin, 2017).

\subsubsection{COIL}

One of the most known models of VE is COIL, a model which stems from SUNY and is popular due to the administrative support it provides to its member institutions through the Center for COIL at SUNY and the Nodal Network (Rubin, 2016a). The Center for COIL assists in facilitating online learning and building relationships with international partners. The Center for COIL involves instructors and administrators in the planning process, which helps develop VE programs quickly and more efficiently. The COIL center offers several design models of VE and access to a vast international network. Rubin (2017) explains:

"COIL is not a technology or a technology platform but rather a new teaching and learning paradigm that develops cross-cultural awareness across shared multicultural learning environments...COIL is based upon developing team taught learning environments where teachers from two cultures work together to develop a shared syllabus, emphasizing experiential and collaborative student learning” (p. 33). 
This new modality of providing global experiences to students through the use of technology, due to its experiential and collaborative nature, has the potential to serve as a solution to the accessibility problem experienced by many students who are unable to study abroad.

Ruiz-Corbella (2014) sees VE as an inclusion strategy in higher education, providing access to global experiences to students with differing ability statuses, financial means, and family commitments requiring alternative options for obtaining global experiences which do not require mobility. Rubin (2017) underlines "three parallel phenomena: broader university engagement with online technology, the widespread use of social networks, and the increasingly pervasive fear of terrorism" (p. 30) as factors that contribute to the popularity and necessity of VE programing in the higher education settings. He states "[f]aculty and students are now usually comfortable working and engaging with each other online, while they are often less at ease with international travel to many destinations" (Rubin, 2017, p. 30). Rubin (2016a, 2017) argues that COIL has the potential to help individuals overcome their fears of travel by connecting students to each other in a safe virtual setting without the added expense and possible danger of travel. He and several other scholars argue that although institutions remain committed to study abroad and student mobility, they are more widely embracing COIL as they seek ways to make such experiences accessible to all (Guth \& Rubin, 2015; O’Dowd, 2018; Rubin, 2016a, 2017; Ruiz-Corbella, 2014). VE has become an important experiential modality for the internationalization of students unable to study abroad (O'Dowd, 2018; O’Dowd \& Lewis, 2016; Rubin, 2016a, 2017; Ruiz-Corbella, 2014) and has since evolved to many other models beyond COIL. Table 2 below lists the models, their key features, and the frequency with which they were mentioned in the reviewed literature.

\section{Table 2. Models of VE}

\begin{tabular}{|l|l|l|l|}
\hline Type of Model & Key Features & $\begin{array}{l}\text { Frequency } \\
\text { Mentioned }\end{array}$ & Literature \\
\hline COIL & $\begin{array}{l}\text { None discipline specific, } \\
\text { Interculture Learning }\end{array}$ & 5 & $\begin{array}{l}\text { Guth and Rubin (2015); 0’Dowd } \\
\text { (2018); Rubin (2016a, 2016b, } \\
\text { 2017); Ruiz-Corbella (2014) }\end{array}$ \\
\hline Xculture (Virtual Teams) & $\begin{array}{l}\text { Business Model, Global } \\
\text { Competencies in the Workplace }\end{array}$ & 1 & 0’Dowd (2019) \\
\hline E-tandem & Language Learning & 1 & O’Dowd (2019) \\
\hline Telecollaboration & Language Learning & 3 & $\begin{array}{l}\text { Caluianu (2019); Guth and Helm } \\
\text { (2012); O’Dowd (2019) }\end{array}$ \\
\hline Soliya & $\begin{array}{l}\text { Peace Building, Cross-cultural learning } \\
\text { between MENA region and the West }\end{array}$ & 3 & $\begin{array}{l}\text { Elliott-Gower and Hill (2015); } \\
\text { O'Dowd (2019); Rubin (2016b) }\end{array}$ \\
\hline $\begin{array}{l}\text { Online Intercultural } \\
\text { Exchange (OIE) }\end{array}$ & Internationalization, Global Citizenship & 1 & De Wit (2016) \\
\hline
\end{tabular}




\subsubsection{Other models of $V E$}

Since the development of COIL many other models of VE have emerged creating a lack of standardized terminology, which poses a hindrance for researchers in this emerging field. In the European context, VE programs are often referred to as OIE and are intended to serve as a cost effective way to internationalize students and offer global citizenship learning (De Wit, 2016). O'Dowd (2019) attempts to clarify the VE terminology and provide an explanation of the various models which exist, yet universities across the world continue to complicate the field by creating new program names in an attempt to coin their own model of VE. For example, at St. John's University VE programs are referred to as Global Online Learning Exchanges (GOLE) and at DePaul University such programs are called Global Learning Experiences (GLE). O’Dowd (2019) outlines four major models of VE including COIL, as well as providing case studies of two of the models in order to illustrate their strengths and weaknesses in facilitating language and intercultural learning. Aside from COIL the models discussed by O’Dowd (2019) are discipline specific. Xculture (often referred to as Virtual Teams) is a business model which exposes students to global competencies in the workplace. E-tandem is a language learning VE model that encourages students to take ownership of their learning process. Telecollaboration is another language learning VE model that requires classroom integration and shares many similarities with COIL, but unlike COIL is focused only on language learning (O’Dowd, 2019). Caluianu (2019) discusses the challenges of running a multi-year telecollaboration program between Japan and Romania - underlying the importance of institutional buy-in. Guth and Helm (2012) examined the development of multiliteracies through task design within a telecollaboration model between Italy and Germany (where English served as the common language). Finally, there are also organizations, such as Soliya, which serve as facilitators of mentorled, cross-cultural exchanges between the West and the Muslim and Arab world (Elliott-Gower \& Hill, 2015; O'Dowd, 2019; Rubin, 2016a). Despite the fact that each model is a bit different in terms of program design they all serve a similar purpose to facilitate opportunities for intercultural learning and communication via a virtual modality - opening up such opportunities to students who are unable to partake in a study abroad program.

\subsection{VE learning outcomes}

Universities and institutions in the United States and abroad which facilitate VE programs are noting varying learning outcomes such as: language learning, peacebuilding, and international cultural competency development. It is important to note that, although certain models of VE are focused on generating one particular result for example fluency in a foreign language, the reality of these virtual global interactions is that they often produce a wide array of learning outcomes. The VE learning outcomes found in the reviewed literature are depicted in Table 3 below. 
Table 3. VE learning outcomes

\begin{tabular}{|l|l|l|}
\hline Learning Outcome & $\begin{array}{l}\text { Frequency } \\
\text { Mentioned }\end{array}$ & Literature \\
\hline Language Learning & 8 & $\begin{array}{l}\text { Barbier and Benjamin (2019); Gay (2013); Guadamillas } \\
\text { Gómez (2017); Guth and Helm (2012); Hagley (2016); } \\
\text { Helm (2017); O’Dowd (2018); Patterson et al. (2012) }\end{array}$ \\
\hline $\begin{array}{l}\text { International Cultural } \\
\text { Competency Development }\end{array}$ & 6 & $\begin{array}{l}\text { Bassani and Buchem (2019); Custer and Tuominen (2016); Hagley } \\
\text { (2016); Helm and Guth (2012); Li (2012); Rubin (2017) }\end{array}$ \\
\hline Peace Building & 5 & $\begin{array}{l}\text { Akbaba and Başkan (2017); Elliott-Gower and Hill (2015); } \\
\text { O’Dowd (2019); Rubin (2016b), Ruiz-Corbella (2014); }\end{array}$ \\
\hline
\end{tabular}

\subsubsection{Language learning}

The largest subset of research on VE focuses on the language learning aspect VE has the potential to facilitate (e.g. Barbier \& Benjamin, 2019; Guadamillas Gómez, 2017; Guth \& Helm, 2012; Hagley, 2016; Helm, 2017; O’Dowd, 2018; Patterson et al., 2012). In language learning, one-on-one interactions, whether virtual or in person, play an important role in increasing vocabulary and improving fluency. Thus, courses focused on language learning that implement the VE model offer benefits to student learning, especially when one-to-one synchronous peer-to-peer interactions are a possibility (Barbier \& Benjamin, 2019; Helm, 2017). Helm (2017) further complicates the notion of seeing the native speaker as the ideal conversation partner to facilitate language learning. Arguing that this idea ascribes a single native language to a nation, which often oversimplifies the cultural and linguistic makeup of the community and with that further perpetuates the Westerncentric viewpoint. Barbier and Benjamin (2019) warn that there are many complexities connected to English being the dominant instructional language in VE programs and stress that culturally appropriate materials and texts are essential given the multicultural nature of the students in such programs. As with any global interactions it is important that we move away from Westerncentric approaches and co-create spaces in which the opinions, experiences, and cultures of all participants are mutually valued, respected, and important. In the VE model, where the planning and design stage of the program is a collaborative process of faculty or facilitators from both countries, this should not be difficult to attain if culturally responsive pedagogy is brought into the process (Gay, 2013).

\subsubsection{International cultural competency development}

A learning outcome which seems to be focal in most international programs is that of international cultural competency building. In the VE context this learning outcome emerges both in research 
focused on this topic and as a subset in research focusing on other aspects of VE, such as language learning and program design. Li (2012) examines and evaluates the experiences of students who partook in a VE within the business school curriculum at institutions in the United States and China and provides evidence that global competence is teachable with appropriate learning opportunities. He urges the American higher education community to take action as American students lack in global knowledge and skills. Custer and Tuominen (2016) respond to this call for the need of internationalization of American students, especially those in community colleges as their access to global mobility is much more limited (Rubin, 2017). It is important to note that many factors play into the intercultural development of students including language skills and cultural differences of modesty, which can affect students' self-reported cultural gains (Custer \& Tuominen, 2016). Despite this challenge, Custer and Tuominen (2016) indicate that the students in their study found value in the VE interactions and were pleasantly surprised at their ability to find common ground with their international peers.

Bassani and Buchem (2019) conducted a case study with participants of a VE program intended to increase the intercultural competence of students in Brazil, France, and Germany. The findings showed that student engagement was negatively impacted by their low confidence in their ability to communicate in English. Due to this issue, students mostly engaged during predetermined class times and their engagement outside of these times was limited. Furthermore, the final evaluation stage of this study provided evidence that students' low confidence in navigating differing cultural work environments was a barrier to their intercultural learning (Bassani \& Buchem, 2019). This study once again highlights the problem of using English as the main language of communication in most VE programs and the need for fluent or at the least comfortable communication in order to facilitate engagement and foster intercultural growth. Interestingly, Hagley (2016) advocates for the need of more VE programs offered to English as a Second Language learners because this student population's mobility is typically limited; thus, utilizing virtual exchange programming can assist with cultural exposure and reduce access concerns. Helm and Guth (2012) warn that research shows that students engaging online with others with similar views is problematic as true intercultural learning cannot take place unless the instructor is willing to discuss and introduce difficult and sensitive topics in the classroom.

\subsubsection{Peace building}

Another emerging thread in VE research focuses on peace building as a major learning outcome. The Soliya model of VE is introduced as the model which connects small groups of students from Western countries with their counterparts in Muslim-majority or Arab countries facilitating safe, 
meaningful discussions to build understating and empathy (Elliott-Gower \& Hill, 2015; O’Dowd, 2019, Ruiz-Corbella, 2014). Soliya is an organization that facilitates VE programs for an array of educational institutions and is part of the VE Coalition. Elliott-Gower and Hill (2015) present a case study of two faculty leading a course facilitated by Soliya at two universities in Georgia. Soliya led a VE which fostered empathy among the participating students through communication with international peers. In addition, both institutions supplemented the VE peer interactions with course readings about Islam and Muslim communities. These course readings helped deepen the students' understanding and provided for a more informed dialogue among the peers. ElliottGower and Hill (2015) emphasize that this course design with international peer interaction grounded in relevant course readings creates a space for constructive dialogue that previously did not exist and is a force which has the potential to lead to peace building. Similar VE programs focused on fostering dialogue on contemporary politics between U.S. and Muslim students are also run at universities without using a third party such as Soliya to facilitate them. Akbaba and Başkan (2017) discuss one such course co-taught between colleges in the U.S. and Turkey, stating that students in both countries found the peer-to-peer interactions in the virtual environment added a value to the course.

Although fostering these virtual platforms for discussion of religion, politics, and alike is an important path toward peace building and increasing tolerance given the current global political environment (Rubin, 2016a), other scholars urge that to truly address present global issues, the VE field needs to move toward a more action-oriented state in which students, rather than conceptualize solutions, actually take action (O'Dowd, 2019). Through the discussion of the limitations and strengths of some of the existing VE models, O'Dowd (2019) proposes a new VE model which focuses on global citizenship education through bringing attention to "themes which are of social and political relevance” (O’Dowd, 2019, p. 11). He recommends that ideologies must be contextualized into what he refers to as societal macro topics, to center on specific global themes in order to be moved into action.

\subsection{VE programmatic insights}

The scholarship on VE mostly consists of case studies sharing analysis of particular programmatic features including planning, curricular, and pedagogical visions. Several scholars offer implementation guidance, including a typology of implementation models and an evaluation process of a pedagogical intervention. The literature also outlines challenges and cautionary tales of unforeseen technological or communication issues. The VE programmatic insights discussed in the reviewed body of literature are explained in Table 4 below. 
Table 4. VE programmatic insights

\begin{tabular}{|l|l|l|l|}
\hline Insight & Key Feature & $\begin{array}{l}\text { Frequency } \\
\text { Mentioned }\end{array}$ & Literature \\
\hline Planning \& Implementation & Guide for Practitioners & 3 & Rubin (2016a, 2017); Guth and Rubin (2015) \\
\hline $\begin{array}{l}\text { Typology, Pedagogy, } \\
\text { Policy \& Practice }\end{array}$ & $\begin{array}{l}\text { Overview of Models } \\
\text { and Approaches }\end{array}$ & 4 & $\begin{array}{l}\text { Akbaba and Başkan (2017); Helm (2018); } \\
\text { O’Dowd and Lewis (2016); 0’Dowd (2018, 2019) }\end{array}$ \\
\hline Assessment & $\begin{array}{l}\text { Evaluation Process, } \\
\text { Pedagogical Intervention }\end{array}$ & 3 & $\begin{array}{l}\text { Bassani and Buchem (2019); Custer } \\
\text { and Tuominen (2016); Li (2012) }\end{array}$ \\
\hline Challenges & $\begin{array}{l}\text { Adequate planning time, } \\
\text { Technological Difficulties, } \\
\text { Underdeveloped } \\
\text { Infrastructure, Logistics and } \\
\text { Communication, Language } \\
\text { Barrier, Different Academic } \\
\text { Schedules, Time Change }\end{array}$ & 6 & $\begin{array}{l}\text { Abrahamse et al. (2014); Bassani and } \\
\text { and Rubin (2015); Rubin (2016a, 2016b, } \\
\text { 2017); Patterson et al. (2012) }\end{array}$ \\
\hline
\end{tabular}

\subsubsection{Planning and implementation}

Rubin (2016a, 2017) and Guth and Rubin (2015) provide a detailed guide for practitioners embarking on the journey of setting up a VE course using the COIL model. Rubin (2016b) discusses the disruptive nature of VEs within the university setting, arguing that such models challenge educators to think about exchanges in a novel way, within a new context. He then offers COIL and its key features as a roadmap to bringing this disruptive pedagogy to life. Akbaba and Başkan (2017) share their experience with using Skype to design and co-teach a VE course. They combined face-to-face instruction with whole-class Skype session were students from the U.S. and Turkey interacted as a group as well as included project teams where students interacted one-on-one. They indicated that logistical challenges were overcome and framed as a way to learn more about the geography, infrastructure, and culture of the other country. The challenge of differing technological infrastructures was also discussed by Abrahamse et al. (2014). They underlined the difficulty of building partnerships and the need for early interventions to improve student-to-student interactions - which can be even more challenging if the technology is not cooperating.

A typology to organize different approaches to teaching VE is offered by O'Dowd (2018) who writes extensively about VE pedagogy, policy, and practice (O’Dowd, 2018, 2019; O'Dowd \& Lewis, 2016). The typology divides the approaches of VE into three implementation models: subject specific, shared syllabus, and service-provider. The subject-specific approach is parsed into two categories: (1) language learning and (2) business studies. In both of the subject-specific categories the instructor is the leader of the exchange and thus a bottom-up method is employed (O'Dowd, 2018). The drawback of this approach is that it is not as engaging for students and can at times feel 
elitist to the international partners. In the shared syllabus model, such as COIL, where courses are designed and taught collaboratively by two or more instructors and increased institutional support is available, there is more equilibrium in the design and implementation process, which presents opportunities for the development of deeper partnerships. The service-provider model, in which the school outsources the VE program to an organization, such as iEarn, Soliya, and Sharing Perspectives which specialize in the facilitation of VE programs, and the planning and implementation of VE is left up to the experts. This typology provides practitioners with a helpful guide to understanding the different design and implementation approaches and the benefits and limitations of each. Helm (2018) engages with the global history and practice of the VE field. She shares examples of successful previous policy and advocates for policy action to move VE into the future through fostering engagement across stakeholders via policy and strategy and cultivating grants.

The importance of assessment of VE programs is discussed as a way to hold students accountable across institutions (Custer \& Tuominen, 2016), as well as a way to improve programming and learn more about student experience and perspective (Bassani \& Buchem, 2019; Li, 2012). Li (2012) discusses the creation and evaluation process of a pedagogical intervention, which served to provide students from China and the United States opportunities to collaborate virtually on international business research projects. Although Li's (2012) pilot study is specific to this one experimental case, it offers opportunities for others seeking to increase their students' global knowledge to use this intervention as a model for shaping their own VE pedagogy. Bassani and Buchem (2019) evaluated their program in three phases. In phase one they assessed their planning of the course, and in phase two and three they employed two surveys to evaluate the student experience. They found that the language barrier played a negative role, as did the fact that students did not engage past class time. They also found that students had difficulty navigating work environments within different cultural settings.

\subsubsection{Challenges}

Scholars warn about the care and time that is needed to adequately plan a VE course, especially if it is intended to be collaborative (Bassani \& Buchem, 2019; Caluianu, 2019; Rubin, 2016a, 2017; Guth \& Rubin, 2015; Patterson et al., 2012). Bassani and Buchem (2019) present a case study in which they examine planning, implementation, and evaluation phases of the VE experience. The authors emphasize the need for a longer planning stage during which ample time is dedicated to testing technological platforms - a lesson learned from issues that arose during their hastily planned course. Similarly, Patterson et al. (2012), present cautionary tales based on the design and implementation process of their VE course in which they experienced numerous technological difficulties due to the underdeveloped infrastructure within Colombia. They also noted problems with logistics and communication due to the language barrier, different academic schedules, and a time change amid 
the semester. The authors conclude that such challenges can be avoided with careful planning or can be corrected/adjusted while the course is in progress (as was in their case). They conclude by noting that despite these challenges the students enjoyed the VE experience and wish to pursue similar opportunities in the future (Patterson et al., 2012).

\section{Conclusions and implications}

This integrative literature review sheds light on themes, trends, and limitations discussed in English language publications on VE over a span of a decade. More specifically the review serves as a short introductory synthesis of the topics scholars have explored within this field, who the key players are, what some of the various models of VE are, what the major learning outcomes are, and what are some of the most commonly discussed programmatic insights. Finally, and most importantly, this synthesis brings to the surface two key gaps present in current literature; (1) lack of methodological diversity in the published studies - most are qualitative and many use the case study methodology, and (2) insignificant empirical exploration of the faculty/facilitator experience in planning and executing VE programs. Future research should therefore focus on explorations which explore quantitative and mixed methods as well as other types of qualitative methods such as grounded theory, ethnography, phenomenology, and the like. In addition, scholars should focus on empirical explorations of the faculty/facilitator experiences within VE to understand the curricular and programmatic decisions made and in turn understand how they affect the learning outcomes of the students. This will add an important missing piece to the scholarship on virtual exchange.

\section{Acknowledgments}

A heartfelt thank you to the reviewers, and to Dr Sandra Abrams and Dr Nancy Morabito for their guidance and support.

\section{References}

Abrahamse, A., Johnson, M., Levinson, N., Medsker, L., Pearce, J. M., Quiroga, C., \& Scipione, R. (2014). A virtual educational exchange: a north-south virtually shared class on sustainable development. Journal of Studies in International Education, 19(2), 140-159. https://doi.org/10.1177/1028315314540474

Akbaba, Y., \& Başkan, F. (2017). How to merge courses via Skype? Lessons from an international blended learning project. Research in Learning Technology, 25. https://doi.org/10.25304/rlt.v25.1915 
Barbier, R., \& Benjamin, E. (2019). From 'CoCo' to 'FloCoCo': the evolving role of virtual exchange (practice report). In A. Turula, M. Kurek \& T. Lewis (Eds), Telecollaboration and virtual exchange across disciplines: in service of social inclusion and global citizenship (pp. 23-29). Research-publishing.net. https://doi.org/10.14705/rpnet.2019.35.936

Bassani, P., \& Buchem, I. (2019). Virtual exchanges in higher education: developing intercultural skills of students across borders through online collaboration. Revista Interuniversitaria de Investigación en Tecnología Educativa, 6 , 22-36. https://doi.org/10.6018/riite.377771

Byker, E. J., \& Putman, S. M. (2019). Catalyzing cultural and global competencies: engaging teachers in study abroad to expand the agency of citizenship. Journal of Studies in International Education, 23(1), 84-105. https://doi. org/10.1177/1028315318814559

Caluianu, D. (2019). When more is less: unexpected challenges and benefits of telecollaboration. In A. Turula, M. Kurek \& T. Lewis (Eds), Telecollaboration and virtual exchange across disciplines: in service of social inclusion and global citizenship (pp. 7-13). Research-publishing.net. https://doi.org/10.14705/rpnet.2019.35.934

Chen, B. (2017 August 23). Dear iPhone: here’s why we're still together after 10 years. New York Times. https://www. google.com/amp/s/www.nytimes.com/2017/08/23/technology/personaltech/iphone-10-years.amp.html

CultureWizard. (2018). Trends in high-performing global virtual teams. culturewizardBecomeOne. https://content. ebulletins.com/hubfs/C1/Culture\%20Wizard/LL-2018\%20Trends\%20in\%20Global\%20VTs\%20Draft\%2012\%20 and\%20a\%20half.pdf

Cushner, K. (2007). The role of experience in the making of internationally-minded teachers. Teacher Education Quarterly, 34(1), 27-39. https://files.eric.ed.gov/fulltext/EJ795140.pdf

Custer, L., \& Tuominen, A. (2016). Bringing "internationalization at home" opportunities to community colleges: design and assessment of an online exchange activity between U.S. and Japanese students. Teaching Sociology, 45(4), 347357. https://doi.org/10.1177/0092055X16679488

De Wit, H. (2016). Internationalisation and the role of online intercultural exchange. In R. O’Dowd \& T. Lewis (Eds), Online intercultural exchange: policy, pedagogy, practice (pp 69-82). Routledge.

Elliott-Gower, S., \& Hill, K.W. (2015). The Soliya Connect Program: two institutions' experience with virtual intercultural communication. eJournal of Public Affairs, 4(1), 114-140. https://digitalcommons.kennesaw.edu/facpubs/3385/

Gay, G. (2013). Teaching to and through cultural diversity. Curriculum inquiry, 43(1), 48-70. https://doi.org/10.1111/curi.12002

Guadamillas Gómez, M. V. (2017). Building global graduates and developing transnational professional skills through a telecollaboration project in foreign language education. In C. Álvarez-Mayo, A. GallagherBrett \& F. Michel (Eds), Innovative language teaching and learning at university: enhancing employability (pp. 49-58). https://doi.org/10.14705/ rpnet.2017.innoconf2016.654

Guth, S. (2019, March). Exploring the impact of different factors on the development of global citizenship through virtual exchange. In 2019 conference of the American Association for Applied Linguistics (AAAL). AAAL.

Guth, S., \& Helm, F. (2012). Developing multiliteracies in ELT through telecollaboration. ELT Journal, 66(1), 42-51. https:// www.researchgate.net/publication/273370405

Guth, S., \& Rubin, J. (2015). How to get started with COIL. In A. Moore \& S. Simon (Eds), Globally networked teaching in the humanities: theories and practices. Routledge. https://doi.org/10.4324/9781315754925 
Hagley, E. (2016). Making virtual exchange/telecollaboration mainstream - large scale exchanges. In S. Jager, M. Kurek \& B. O'Rourke (Eds), New directions in telecollaborative research and practice: selected papers from the second conference on telecollaboration in higher education (pp. 225-230). Research-publishing.net. https://doi.org/10.14705/ rpnet.2016.telecollab2016.511

Helm, F. (2017). Critical approaches to online intercultural language education. In S. Thorne \& S. May (Eds), Language, education and technology. Encyclopedia of language and education (3rd ed.). Springer. https://doi.org/10.1007/978-3319-02237-6_18

Helm, F. (2018). The long and winding road... Journal of Virtual Exchange, 1, 41-63. https://doi.org/10.14705/rpnet.2018. jve. 3

Helm, F., \& Guth, S. (2012). Open intercultural dialogue: educator perspectives. Journal of E-Learning and Knowledge Society, 8(3). https://doi.org/10.20368/1971-8829/648

Kuh, G. D., O'Donnell, K., \& Reed, S. D. (2013). Ensuring quality \& taking high-impact practices to scale. Association of American Colleges and Universities.

Li, Y. (2012). Cultivating student global competence: a pilot experimental study. Decision Sciences Journal of Innovative Education, 11(1), 125-143. https://doi.org/10.1111/j.1540-4609.2012.00371.x

Lörz, M., Netz, N., \& Quast, H. (2016). Why do students from underprivileged families less often intend to study abroad? Higher Education, 72, 153-174. https://doi.org/10.1007/s10734-015-9943-1

NACE. (2019 March 29). The four career competencies employers value most. https://www.naceweb.org/career-readiness/ competencies/the-four-career-competencies-employers-value-most/

NAFSA. (2018). Trends in U.S. study abroad. U.S. students abroad section. https://www.nafsa.org/policy-and-advocacy/ policy-resources/trends-us-study-abroad

O'Dowd, R. (2018). From telecollaboration to virtual exchanges: state-of-the-art and the role of UNICollaboration in moving forward. Journal of Virtual Exchange, 1, 1-23. https://doi.org/10.14705/rpnet.2018.jve.1

O'Dowd, R. (2019). A transnational model of virtual exchange for global citizenship education. Language Teaching, 53(4), 477-490. https://doi.org/10.1017/S0261444819000077

O’Dowd, R., \& Lewis, T. (2016). (Eds). Online intercultural exchange: policy, pedagogy, practice. Routledge.

Onwuegbuzie, A., \& Frels, R. (2016). 7 Steps to a comprehensive literature review: a multimodal \& cultural approach. Sage.

Patterson, L. M., Carrillo, P. B., \& Salinas, R. S. (2012). Lessons from a global learning virtual classroom. Journal of Studies in International Education, 16(2), 182-197. https://doi.org/10.1177/1028315311398665

Reysen, S., \& Katzarska-Miller, I. (2013). A model of global citizenship: antecedents and outcomes. International Journal of Psychology, 48(5), 858-870. https://doi.org/10.1080/00207594.2012.701749

Reysen, S., Larey, L. W., \& Katzarska-Miller, I. (2012). College course curriculum and global citizenship. International Journal of Development Education and Global Learning, 4(3), 27-40. https://www.researchgate.net/ publication/255718619

Rubin, J. (2016a). The collaborative online international learning network. In R. O'Dowd \& T. Lewis (Eds), Online intercultural exchange: policy, pedagogy, practice (pp. 236-272). Routledge. 
Rubin, J. (2016b). Nautical musings on local and global innovation and change: the disruptive pedagogy of COIL. In E. Jones et al. (Eds), Global and local internationalization (pp. 75-79). Sense Publishers.

Rubin, J. (2017). Embedding Collaborative Online International Learning (COIL) at higher education institutions. Internationalization of Higher Education: A Handbook, 2, 27-44.

Ruiz-Corbella, M. (2014). Virtual mobility as an inclusion strategy in higher education: research on distance education master degrees in Europe, Latin America and Asia. Research in Comparative and International Education, 9(2), 165180. https://doi.org/10.2304/rcie.2014.9.2.165

Salisbury, M. H., An, B. P., \& Pascarella, E. T. (2013). The effect of study abroad on intercultural competence among undergraduate college students. Journal of Student Affairs Research and Practice, 50(1), 1-20. https://doi.org/10.1515/ jsarp-2013-0001

Slotkin, M. H., Durie, C. J., \& Eisenberg, J. R. (2012). The benefits of short-term study abroad as a blended learning experience. Journal of International Education in Business, 5(2), 163-173. https://doi.org/10.1108/18363261211281762

Taras, V., Baack, D., Caprar, D., Jimenez, A., \& Froese, F. (2021 June 9). Research: how cultural differences can impact global teams. Consumer behavior. Harvard Business Review. https://hbr.org/2021/06/research-how-culturaldifferences-can-impact-global-teams

Thorne, S. L. (2016). Forward: the virtual internationalization turn in language study. In R. O’Dowd \& T. Lewis (Eds), Online intercultural exchange: policy, pedagogy, practice (pp. ix-xi). Routledge.

Varela, O. E. (2017). Learning outcomes of study-abroad programs: a meta-analysis. Academy of Management Learning \& Education, 16(4), 531-561. https://doi.org/10.5465/amle.2015.0250

Walters, L. M., Garii, B., \& Walters, T. (2009). Learning globally, teaching locally: incorporating international exchange and intercultural learning into pre-service teacher training. Intercultural Education, 20(sup1), S151-S158. https:// doi.org/10.1080/14675980903371050

Wearden, G. (2011 May 10). Skype: from start-up to \$8.5bn sale. The Guardian.com. https://www.google.com/amp/s/amp. theguardian.com/technology/2011/may/10/skype-timeline-start-up-sale 


\section{Virtual Exchange?}

Published by University of Groningen Press | UGP, a not-for-profit press

Groningen, The Netherlands | UGP@rug.nl

(C) 2021 UNICollaboration (collective work)

(C) 2021 by Authors (individual work)

Journal of Virtual Exchange 2021

Edited by Carolin Fuchs and Müge Satar

Publication date: 2021/11/05

Journal of Virtual Exchange (JVE) is an online, open-access, peer-reviewed journal aimed at practitioners and researchers in the field known variously as virtual exchange, telecollaboration, or online intercultural exchange. It is the official journal of UNICollaboration (https://www.UNICollaboration.org/), the international academic organisation dedicated to supporting and promoting telecollaboration and virtual exchange in higher-level education.

Rights. The whole volume is published under the Attribution-NonCommercial-NoDerivatives 4.0 International licence (CC BY-NCND 4.0); individual articles may have a different licence. Under the CC BY-NC-ND licence, the volume is freely available online for anybody to read, download, copy, and redistribute provided that the author(s), editorial team, and publisher are properly cited. Commercial use and derivative works are, however, not permitted.

Disclaimer. University of Groningen Press does not take any responsibility for the content of the pages written by the authors of this article. The authors have recognised that the work described was not published before, or that it was not under consideration for publication elsewhere. While the information in this article is believed to be true and accurate on the date of its going to press, neither UniCollaboration nor University of Groningen Press can accept any legal responsibility for any errors or omissions. Additionally, the publisher makes no warranty, expressed or implied, with respect to the material contained herein. While University of Groningen Press is committed to publishing works of integrity, the words are the authors' alone.

Trademark notice. Product or corporate names may be trademarks or registered trademarks, and are used only for identification and explanation without intent to infringe.

Copyrighted material. Every effort has been made by the editorial team to trace copyright holders and to obtain their permission for the use of copyrighted material in this article. In the event of errors or omissions, please notify the publisher of any corrections that will need to by incorporated in future editions of this article.

Typeset by Research-publishing.net (https://research-publishing.net)

Noto fonts are open source. All Noto fonts are published under the SIL Open Font License, Version 1.1. Noto is a trademark of Google Inc. (https://www.google.com/get/noto/).

ISSN: 2647-4832 (online only)

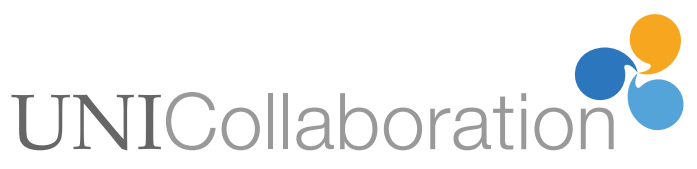

